\title{
Research Paper Analysis of adoption of recommended cultivation practices by lime growers of north Karnataka
}

\author{
Jameer R. Attar and S. G. Aski
}

Correspondence to :

\section{S.G. Aski}

Department of Agricultural

Extension Education,

College of Agriculture,

University of Agricultural

Sciences, Dharwad

(Karnataka) India

Paper History :

Received : 06.09.2017;

Revised : 20.01.2018;

Accepted : 04.02.2018
ABSTRACT : Fruits are of great importance in the field of human nutrition. Citrus is one of the most important fruit crop in India. Citrus fruits have a special place in Indian diet as they are rich source of vitamin C, vitamin A, vitamin B and fruit sugars. The present investigation was conducted in Vijayapura and Kalaburagi district of Northern Karnataka in the year 2013-14. A sample size of 140 respondents who have minimum one acre of lime orchard and who have at least five years and above old orchard were selected randomly. The data was collected through personal interview method with the help of structured interview schedule. The results indicates that, comparatively more number $(42.14 \%)$ of farmers belonged to medium adoption category, followed by high $(34.29 \%)$ and low (23.57 \%) adoption category. It was also observed that, education, land holding, annual income, extension contact, mass media participation, experience in lime cultivation and economic motivation found to have positive and significant relationship with the adoption level of lime growers.

KeY Words : Adoption, Citrus fruits, Lime growers

How To Cite This Paper : Attar, Jameer R. and Aski, S.G. (2018). Analysis of adoption of recommended cultivation practices by lime growers of north Karnataka. Internat. Res. J. Agric. Eco. \& Stat., 9 (1) : 120-124, DOI : 10.15740/HAS/IRJAES/9.1/120-124. 